\title{
RESENHA
}

\section{A "restauração" do Rio Grande}

Tau Golin*

Curiosamente, o acontecimento histórico que propiciou a consolidação do núcleo administrativo, militar e social rio-grandense, é também um dos mais desconhecidos. Trata-se dos 13 anos de ocupação castelhana da vila de Rio Grande e de parte dos imensos territórios incorporados por Portugal, após ultrapassar o meridiano de Tordesilhas. Através de uma reinvestida que mobilizou os súditos castelhanos do Rio da Prata e de contingentes militares europeus, as duas coroas disputaram o espaço sulino em uma guerra que teria conseqüências futuras e assumiria papel preponderante na geopolítica meridional.

Parte dessa história, o coronel-historiador Cláudio Moreira Bento está contando em A Guerra da Restauração, livro editado pela Biblioteca do Exército Editora.' O autor fortalece as contribuições de Abeillard Barreto e de Jônathas da Costa Rego Monteiro, dois especialistas no tema. Todavia, Moreira Bento não escreve especificamente um livro "de autoria" sobre a (re)ocupação de Rio Grande. Ele se coloca em papel mais modesto. Aparentemente despretensioso, apenas apresenta, acrescenta notas à tradução de Memórias Relativas à Expedição ao Rio Grande (1774 a 1779), do Tenente-General João Henrique

Jornalista, historiador, professor da Universidade de Passo Fundo, RS, Brasil.

1 Bento, Cláudio Moreira. A Guerra da Restauração. Rio de Janeiro: Biblioteca do Exército Editora, 1996. 
Böhm, e suas cartas ao vice-rei Lavradio, que circulava entre os historiadores em francês.

Böhm era de Bremen e teve como mestre o Conde de Lippe, inovador militar, cuja doutrina foi adotada por Pombal na reorganização do exército português. Mandado para o Brasil pelo marquês, de quem era assessor militar, assumiu o comando do Exército do Sul em 1774, depois das operaçôes de contra-ofensiva dirigidas por José Custódio de Sá e Faria e Marcelino de Figueiredo, a partir de 1769.

Os fortes de São Miguel e Santa Teresa, a vila de Rio Grande e São José do Norte haviam sido ocupadas em abril de 1763 , em grande parte pela inépcia do governador Elói Madureira e do comandante Tomás Luís Osório. No lastro do Tratado de Paris, um Convênio de Suspensão de Armas e Limites, assinado em agosto, manteve as tropas nas posições em que se encontravam.

José Custódio assumira o governo em 1764. Profundo conhecedor do território rio-grandense, onde estivera de 1752 a 1761, durante a guerra guaranítica e nas demarcações do Tratado de Madri, lançou as bases organizacionais de um exército que combinava as tropas formais com guerrilheiros, arregimentados em unidades de cavalaria e infantaria, reunindo aventureiros paulistas, paranaenses e catarinenses, além de gaúchos. Estas tropas irregulares continuavam operando durante os armistícios, realidade que motivou a expedição punitiva dos espanhóis de 1773 , comandada pelo governador de Buenos Aires, general Vertiz y Salcedo.

Pombal respondeu com a reorganização do Exército do Sul, sob o comando de Böhm. Ao chegar no Rio Grande, em 1774, ele ampliou a estratégia de Custódio e Marcelino, investindo também em fortificações, aliás um concepção igualmente de José Custódio, mas que não contava com os recursos e poderes do tenente-general, que trouxera tropas de quase todas as regiões do Brasil e mais os regimentos vindos da Europa: Bragança, Moura e Estremoz. Dessa forma, reuniu efetivos que somavam mais de 4.000 homens, além dos guerrilheiros de Cavalaria Ligeira, que operavam a partir de Canguçu e Encruzilhada, e os Caçadores Índios.

Após o fortalecimento das frentes de São José do Norte, Rio Pardo e Serra dos Tapes, o Exército do Sul reconquistou a vila de Rio Grande em abril de 1777. A Espanha, sob o comando de Cevallos ocupou imediatamente a Ilha de Santa Catarina e a Colônia de Sacramento. Quando o cerco se fechava contra o Rio Grande português, 
após a morte de D. José I e a queda de Pombal, os dois reinos ibéricos assinaram o Tratado de Santo Ildefonso, em outubro, remarcando a linha de fronteira, onde já se verificou uma ampliação do território brasileiro.

De difícil visualização era um outro processo, o qual operava na consolidação da sociedade rio-grandense: a relação entre governo e grupos particulares diretamente interessados, além de milhares de aventureiros, gaúchos, gaudérios, mestiços, andejos e ladrões de campo, que tinham nesses conflitos a possibilidade de sobrevivência. Gestava-se, estruturalmente, uma organização social em que se fusionavam laços indestrutíveis entre o Estado e a elite da terra (ainda em formação), onde os territórios disputados/incorporados combinavam a expansão geopolítica e a formação de novas propriedades.

Nesse processo, a restauração significou a alquimia de um núcleo político-social emulador do futuro, cujo poder consolidador de estruturas sociais se imporia aos próximos séculos e, de certa forma, revela a essência rio-grandense. Significou o momento de transição e superação do Rio Grande pioneiro. A guerra uniu e deu consistência aos povoamentos. Algumas estruturas administrativas foram solidificadas, onde Porto Alegre passou à capital nessa lógica. Conformou-se um embrião do estado futuro. Solidificado no espaço da planície litorânea e vale do Jacuí, posteriormente, pôde ir fazendo novas incorporações, até a definição da fronteira. Os litígios derradeiros foram resolvidos apenas em 1927, sem implicar ainda no abandono do sentimento de perda manifestado por muitos historiadores e intelectuais uruguaios.

Ler A Guerra da Restauração é operar diretamente no centro privilegiado da formação do Rio Grande. Aqui, o termo "restauração" pode significar igualmente "fundação" da sociedade sul-rio-grandense. 